\section{ON TYPHUS FEVER,}

\section{AND ITS TREATMENT BY ALKALIES.}

\section{By Paul Srade Kinight, M.D.}

IN September last I published a letter in The Lancer, expressive of the great satisfaction I derived from a lecture on typhus fever by Dr. Clanny; and at the same time, I stated that "I had also deviated from the generally adopted methods of treat. ing this chicf of diseases, and that I would take the earliest opportunity to submit the results to the public." "The Durbam County Advertiser" of the 12th instant having been kindly sent to me by $\operatorname{som} \theta$ unknown hand, for which however I am much obliged, I see in it a high and just tribute paid to the very valuable researches of $D r$. Clanny and also to Dr. Stevens, who, I learn, has, subsequently to my observations on Dr. Clanny's lecture, read a paper on the subject before the Royal College of Physicians, and I therefore consider that the individual who has sent me the Durham paper, has done it to prompt me to perform my promise. In obedience to this call, al. though the opportunity alluded to has not arrived, I beg to make public the following facts relative to four cases of typhus, two taken promiscuously, and two for an especial purpose, and this $I$ do with the more confidence, as I find myself supported by Doctors Clanny and Stevens. In the letter before allnded to, I stated "I thought I had observed that certain medicines exercise a very beneficial influence in the cure of in. sanity by their action on the stomach and head, and therefore since my residence in this place, I proceeded to ascertain its effects on headachs generally as they occur in the sane; the effects emboldened me to adopt it first in mental irritation, and ultimately in typhus fever; the result has exceeded my sanguine expectations." Since this was written, Mr. Editor, I have lost no opportunity to prosecute the important and interesting inquiries; and though my opportunities in treating typhus have not been equal to those of the learned gentlemen above referred to, yet as my practice has extended to a great variety of diseases, 1 trust scientifically, altogether comprising many hundred cases, all bearing on the same point, my testimony to the astonishing success attending the use of alkaline medicines in typhus fever cannot be useless, as I rest on nothing but the fact for its ralue. I must beg you will be so kind as to afford me a little of your valuable space, and I will compress what I have to say into the smallest room I can.
Cases abridged from a Selection in my Case Book.

February 24, 1828. Miss -, aged 19, was a delicate and very retired young lads. I found her very delirious, and acting re. versely to her natural manner; her disease was a compound of typhoid delirium, and what is termed the high state in insanity. I took away twenty ounces of blood, gave im. mediately, subm. hydr. gr. $v$, and an effer. vescing draught every four hours.

25. No alteration; bowels moved but slightly. Continue the draught. Take

$$
\begin{aligned}
& \text { Bo Subm.hydr., gr. vi ; } \\
& \text { Pulv.jalap., gr. viij. Statim. }
\end{aligned}
$$

26. Bowels effectually unloaded, but de. lirium and mental irrirability unabated; shrinks on pressing the epigastrium.

$\mathrm{B}_{\mathrm{o}}$ Potass.carbonas, $\mathrm{j}^{\mathrm{ij}}$;

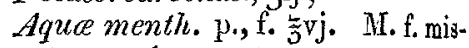
tur. cujus capt. quart. part. Gà. q. horâ.

27. Rational. Continue mistur, alhal, From this day she became convalescent, and was perfectly well on the 5th of March, and very little the worse for the fever.

A pril 20, 1829. Mrs. W-, aged 34, a thin little woman, whom $I$ had attended in pleurisy some months prior, had typhus of a low type. Emetic; imprimis, calomel bolus, then

R Subcarb. soda, $3^{i j}$;

Spt. ath. nitro., ปsss;

Aq. menth. p. q. s. ft. h. Lss. M. f. mist. cujus capiat coch. ij. 4h. quále que horâ.

21. Up and collected, but feels giddy when standing. Cont.

22. Continues rational; less giddy; sound sleep. Cont.

23. All symptoms of fever subsiding. Cont.

24. Convalescent.

27. Quite recovered.

Betty Schole's son.-I was requested to see this boy, who was about nine years old, 21st A pril, 1829, eight days after ho had been attacked with typhus fever. He had been under the care of an apothecary, who told me he had applied eight leeches to the temples, and yiven saline medicines. His pulse was 108, and thready; could not rise in bed; was perfectly delirious; lips dry; teeth covered with sordes; tongue parcbed; skin crisp; eyes languid and inexpressire; thirst very troublesome, which was attempted to be alloyed, as usual, by oranges, lemon. ade, \&rc. Acids of all linds probibited, and spring water to be substituted, or conmon tea, or toast and water. 
R Sodce carb., $3 \mathrm{j}$;

Sp. eth.n., $3 \mathrm{j}$

Aq. menth. p., $\mathrm{J}^{\mathrm{iv}}$; M. f. mist. capt. coch. ampl. j. 4ầ. q. horâ.

Being at a distance, I did not see him on the 22d, but he was reported better. On the ogrd, countenance intelligent, and he is perfectly collected, \&c. Cont. Sound sleep returned on the 26 th, and his tongue was moist on the 27 th, and clean on the 29th; but his pulse had got up to 120 , from debility, I imagine. He gradually recovered.

In the neighbourhood of these two last cases, and during my attendance on them, I was requested to visit another lad of the same age, who had been under the care of the same medical man, and had received the same treatment. I saw him on the twelfth day of the disease, but he was dying, and I declined giving him any thing.

June 19th, 1829. I was requested to see a gentleman aged 33 . He is a talented and well-informed man. He was aware that he had typhus fever. An emetic immediately.

Bo Sodce subcurb. jiij.;

P. rhei gr. vj. M. f. pulv. in chart.

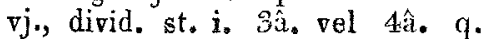
horâ.

20. All febrile symptoms subsided, but he was not perfectly well till ten days after.

A fow months since, I had seven very bad cases at one time in one miserable family. They all recovered, though my fears induced me twice to abandon the alkali, only to be driven to it again as a forlorn hope. I scarcely need arow, that I consider the great cause of all the ailments in the cases I have related, as well as those to which I have alluded, was a peculiar morbid acidity in the stomach; and ample experience, backed as it is by the authority of Drs. Clanny and Stevens, justifies me in strongly recommending the use of the carbonates and subcarbonates of soda and potash, in all fevers of the typhoid character, more especially as I huve not lost a single case in which $I$ have relied on these medi. sines: but I can by no means say so much in recommendation of the neutral salts, or of the effervescing draught, because $I$ am satisfied they are greatly inferior to the alkalies I have named; and I selected the first and third cases to show the decided superiority of the alkalies over both. You can, I doubt not, Sir, easily conceive the very great pleasure I derived from Dr. Clanny's practical researches into the state of the blood in typhus, when I saw how beautifully it harmonised with my own, as I thought, peculiar practice; and the very satisfactory explanation he gave of its remote influence in correcting the blood, by its immediate influence on the contents of the stomach, producing carbonic acid gas.

Glossop, near NIanchester, June 14th.

\author{
PROPOSED SOCYETY OF \\ "6 GENERAL PRACTITIONERS."
}

\section{To the Editor of $\mathrm{TH}_{\mathrm{H}} \mathrm{L}_{\mathrm{ANCET}}$.}

SIR,-The invitation to communicate, given by the "Metropolitan Association of General Practitioners," induces me to offer some remarks thereon; and for that purpose I prefer the pages of The Lancet to the office of their solicitor.

Some such an association is greatly needed, but I am apprehensive that the necessity will be but ill supplied by the " Metropolitan," unless the committee will condescend to adopt some essential additions to their plan, without which the Society must be utterly useless, and serve only to gratify the appetite for notoriety, which may be possessed by its managers. I shall take the liberty to object to its prospectns, in the hope that it may lead to its amendment; for without such emendations, it is entirely unworthy the support of that class which it professes to advocate and protect.

The title is an absurdity, or, at best, a paradox; where is the propriety of calling it "Metropolitan," if it be intended to consist of the whole body? Why not alter this? Why does it not make a provision against the injurious operation of corporate bodies, and the machinations of the exclu. sive practitioners? There is no resolution enjoining the members to refuse to meet "exclusive practitioners," who send their prescriptions to a druggist or pet-apothecary, and take a percentage on the profit. There is no resolution enjoining the members to discourage needless consultations with "exclusive practitioners," which consultations too often tend to fill the pockets of the " exclusive," empty those of the patient, and prejudice the reputation of general practitioners. Let the "Association" enjoin its members to consult each other in cases where it may not be objected to by the patients and friends; an immense advantage wonld accrue to the adoption of this measure; as the emoluments derivable from consultations would be confined chiefly to their own class, the patient must derive always equal, and sometimes greater, benefit from this course, and at a much smaller cost, than by submitting to the iniquitous exactions of the "exclusives." Let the "As" sociation" become a combination; let it organize co-operative branches throughout the country, and in one year the character of the general practitioner will be exalted, and his emoluments increased; the "Association" will have no necessity to make fruitless applications for legislative enactments to establish what is no longer mooted, namely, their right to recover for attendance as well as medicines; and should 